\title{
Increasing the level of justification of state strategic planning
}

\author{
Yurii V. Mishin' ${ }^{1}$, and Aleksandr Yu. Mishin ${ }^{2}$ \\ ${ }^{1}$ State University of Management, 99, Ryazansky Prospekt, Moscow, 109542, Russian Federation \\ ${ }^{2}$ Financial University under the Government of the Russian Federation, 49, Leningradsky Prospekt, \\ Moscow, 125993, Russian Federation
}

\begin{abstract}
The purpose of this work is to prepare proposals to improve the effectiveness of state strategic planning by increasing the level of validity of the planned and forecast calculations. In modern conditions, the main important directions for ensuring the further development of domestic strategic planning are target management and production regulation. In this work, the following issues have been resolved: 1) As a result of the analysis of methodological approaches to strategic planning in the USSR and Russia, the initial methodological premises were identified and the most expedient area of using the above mechanisms of its development was substantiated; 2) Based on the study and scientific generalization of domestic and foreign research in the field of long-term planning, methodological and methodological foundations for creating its regulatory framework have been developed, including principles, procedures, composition and structure; 3) Proposals have been substantiated for the creation in the Russian Federation of a special ministry - strategic development.
\end{abstract}

\section{Introduction}

October 20, 2020, during the discussion at a meeting of the Committee on the Budget of the State Duma of the Russian Federation of the state program "Development of Education", its chairman Andrei Makarov expressed the opinion of the need to abandon the development of state programs as the main mechanism for regulating the economy.

Then, further on October 23 of this year, when considering state programs in the field of economic and energy development, he was asked in a very categorical form, the head of the Ministry of Economic Development of the Russian Federation, Maxim Reshetnikov, to abandon state programs that had proved, in his opinion, over the past 10 years, their inefficiency and work only on the basis of national goals.

True, the minister did not agree with such a "revolutionary" proposal, saying that a complete refusal would lead to the need to create a new system of long-term planning, and most importantly, to the same problems. He however recognized the need to revise and supplement the entire system of state programs, primarily the current target system indicators, adjusting it to the achievement of the President of RF problems.

Earlier, another Minister of Economic Development of the Russian Federation also spoke more definitely on this issue - Maxim, but Oreshkin, who said in an interview with 
RBC last autumn that "state programs have turned into a 'swamp' that needs to be reformed."

Despite a certain superficiality and categorical statements by Andrei Makarov should recognize the validity of such statements. The current situation in the development and implementation of state programs is the result of a number of objective and subjective reasons and errors.

\section{Materials and methodology}

The founders of the theoretical and methodological foundations of national state strategic planning are V. D Kondratyev, V. V. Leontiev and V. L. Kantorovich. [1,2, 3].

The greatest contribution to the development of the theoretical and methodological foundations of state strategic planning, in our opinion, was made by the Russian scientist ND Kondratyev, who laid the theoretical foundations for forecasting and planning activities. In turn, V.L. Leontiev in the mid-20s of the XX century developed a method for constructing an input-output balance. A prominent founder of the mathematical tools for strategic planning is the Russian scientist Leonid Vitalievich Kantorovich, who developed a method of linear programming, which consists in the method solving linear equations (equations of the first degree) through the formation of production programs and the use of facilitating calculations and the achievement of the required results. various methods of their consistent solution.

Description and listing of unsolved problems and shortcomings of the currently existing system and infrastructure of state strategic planning are presented in a large number of scientific works $[4,5,6,7,8,9,10]$. In turn, constructive and, most importantly, well-grounded suggestions for their elimination are given in papers $[11,12,13,14,15,16,17]$.

At present, the main working document governing the development and implementation of national programs are approved by the Ministry of Economic Development of the Russian Federation (from September 16, 2016 №582, as amended. On March 5, 2017). methodical instructions.

The main drawback of the analyzed document is the excessive detailing of organizational issues to the detriment of methodological ones, It discusses in sufficient detail the principles of forming state programs, requirements for goals, indicators used, composition and structure of generated documents (the structure of indicators for eight planned and twelve reporting forms is given). the location of the details that should be contained on the title page, as well as the accuracy of calculations (in thousands of rubles to one decimal place).

These guidelines do not include: the rationale for the goal-setting system and the principles of goal formation in the hierarchical system of state strategic planning, the mechanism for developing the input-output balance for production and distribution of products in physical and value terms, guidelines for determining the funds required for the implementation of program activities, a system of evaluation indicators their effectiveness, as well as the rules for the formation of threshold values of target indicators (indicators) of the state program.

Due to the presence of such significant "white spots" in the regulatory and methodological support, program-targeted management has a number of significant drawbacks, the main of which are: the isolation of development processes by various departments, inconsistency of the most important goals and parameters of sectoral programs with regional strategies, and state programs with programs of regions and territories, lack of consistency of their most important parameters, low accuracy of the forecast and planned calculations, which inevitably leads to their low efficiency. 
Thus, it seems that all of these shortcomings are, in our opinion, the consequence of two main reasons: the first is the incorrect use of the target management method by the Ministry of Economic Development of the Russian Federation as the main tool for the development of state programs, and the second is the lack of information support for forecast and planned calculations. , which leads to a significant decrease (in comparison with real conditions) required for their implementation of the volume of financial resources (federal budget funds).

A comparative assessment of the main methodological approaches to the development of complex programs for technical, social and economic development is presented in Table 1 .

Table 1. Comparative assessment of the main approaches to the use of target program management in the USSR and Russia

\begin{tabular}{|c|c|c|}
\hline \multirow{2}{*}{ Evaluation criteria } & \multicolumn{2}{|c|}{ Regulatory methodological documents } \\
\cline { 2 - 3 } & $\begin{array}{c}\text { Methodological guidelines for } \\
\text { the development and } \\
\text { implementation of state } \\
\text { programs of the Russian } \\
\text { Federation [21] }\end{array}$ & $\begin{array}{c}\text { Methodology } \\
\text { for the } \\
\text { development of } \\
\text { target complex } \\
\text { programs [22] }\end{array}$ \\
\hline $\begin{array}{c}\text { End goal orientation } \\
\text { End-to-end continuous planning of the } \\
\text { control object }\end{array}$ & + & + \\
\hline $\begin{array}{c}\text { Scope of use: } \\
\text { - the most important, complex - all areas of } \\
\text { socio-economic development and budget } \\
\text { allocations }\end{array}$ & + & + \\
\hline $\begin{array}{c}\text { Establishing measurable implementation } \\
\text { results }\end{array}$ & + & + \\
\hline $\begin{array}{c}\text { The presence of a responsible federal } \\
\text { executive body for achieving the final } \\
\text { results }\end{array}$ & + & + \\
\hline $\begin{array}{c}\text { Regular monitoring of performance and } \\
\text { effectiveness }\end{array}$ & + & + \\
\hline
\end{tabular}

According to official data provided by federal executive authorities (portal of state programs), as of November 9, 2020, 46 state programs (programs . Gov. K u / Portal) have been developed and are operating in the Russian Federation. At the same time, 80 executive authorities of Russia are responsible executors, co-executors and participants of these programs . State programs contain about 2000 indicators, and the total volume of their financing is about $70 \%$ of all federal budget expenditures,

The implementation of targeted comprehensive programs involves the coordinated participation of a number of branches of departments and organizations. In the USSR, target complex scientific, technical, economic and social programs, as well as programs for the development of individual regions and large industrial and economic complexes were developed primarily with the aim of solving the most important intersectoral and regional problems. They were the most important component of state plans for the economic and social development of the USSR. At the same time, the criteria for selecting programs were [18]:

- the special importance and cross-sectoral and multi-disciplinary nature of the problems;

- the fundamental novelty of the used technical, organizational and other solutions;

-suschestvovanie certain organizational - economic preconditions - the existence of scientific and technical and industrial potential. 
It should be noted, however, that the second and third criteria are somewhat contradictory, since, in my opinion, fundamentally new original technical solutions are unlikely to have the appropriate scientific and technical, and even more so, production potential available for their implementation.

\section{Results and discussion}

Assessing from the point of view of the above requirements, the "radicalism" of the Ministry of Economic Development of the Russian Federation in the field of target management, first of all, it should be noted that it extends not only to all spheres of socioeconomic development, but also to the directions of budget allocations.

A sharp increase in the number of programs executed, the efficiency of using this control method is significantly reduced. When federal targeted programs were included in the five-year and annual plans for the economic and social development of the USSR, it was envisaged that they would be $100 \%$ (complete) provision with all types of resources. In case of insufficient resources, the most important programs had to be fully supported in the first place. And all other government programs were subject to adjustment and revision in accordance with the actual volumes of allocated resources. It is hardly possible in the current conditions to provide fulfillment of this requirement, since today about $70 \%$ of all allocations from the federal budget are spent on the implementation of only 46 state (without sectoral and regional) programs. Therefore, at present, solving the problem of providing all types of resources for state programs seems to be very problematic and practically impossible, which casts doubt on the feasibility and, most importantly, the effectiveness of using this methodological approach.

Based on this, the area of state strategic planning should be limited to the formation of national economic and intersectoral (interregional) proportions that ensure the most complete solution of the main socio-economic tasks of the planned period. And the establishment of sectoral and intra- industrial proportions, in turn, should be carried out, respectively, in sectoral programs of economic and social development, as well as in plans for the development of Russian vertically integrated corporate structures.

The implementation of such a methodological understanding of the essence and functions of state strategic planning determines the following main directions of its improvement.

1) State strategic planning should be based on a system of aggregated calculations and indicators. At the same time, it is necessary to move away from the practice of developing state programs not only for strategically important industries, areas of socioeconomic development, and, most importantly, areas of budget allocations.

2) When developing federal budgets (plans), the role of general economic indicators and calculations should be significantly increased, characterizing, on the one hand, the main reproductive proportions, and expressing, on the other hand, the main socio-economic tasks of national economic plans (federal budgets). should have a more active influence on the formation of projections for the development of certain types of economic activity and industries. The main tool for improving strategic planning at the national economic level is the introduction into the practical activities of the central executive authorities (Ministries: Economic Development, Industry and Trade) of intersectoral balances, both in kind and in value. The input-output balance in value terms most fully reflects the essence of this method: in it, development indicators are organically combined with general economic indicators - the cost of social and final products, national income, funds for reimbursing material costs, consumption, accumulation, etc. In turn, cross-sectoral the balance in physical terms, despite its obvious drawback, has one very significant feature, namely, the 
possibility of presenting in detailed form the most important cooperation ties between various industries) links.

It seems that under the current conditions it will most actively contribute to the solution of the task - to increase the level of validity of state strategic planning, the development of a combined input-output balance, which would combine the advantages of both the value and its natural forms of input-output balance. Such a balance should, with the necessary degree of detail, reflect the characteristics of production and distribution of the most important types of products, and also contain generalizing indicators of the effectiveness of the version of the national economic plan (federal budget).

The development of an intersectoral balance is based on a system of resource consumption standards that ensure mutual coordination of the main indicators of economic development. This system includes: coefficients of direct costs of material resources, as well as coefficients of capital intensity and labor intensity. Therefore, today the role of these qualitative economic indicators, which are the most important tools for the formation of planned proportions, as well as the main object of analysis when considering the projections of the development of individual industries in the Government of the Russian Federation, should sharply increase .

As noted above, the most important mechanism for implementing the basic principles of strategic planning is production rationing. The main mechanisms and procedures for specifying the basic principles of strategic planning are presented in Table 2.

Table 2. The relationship between strategic planning and production regulation

\begin{tabular}{|c|c|}
\hline Name of the principles of strategic planning & $\begin{array}{c}\text { Implementation methods, mechanisms } \\
\text { and procedures }\end{array}$ \\
\hline $\begin{array}{c}\text { Balance and consistency in priorities, goals, } \\
\text { objectives, activities, resources, as well as the } \\
\text { timing of implementation }\end{array}$ & $\begin{array}{c}\text { Program-targeted management, physical- } \\
\text { value input-output balance, balances by main } \\
\text { types of economic activity and institutional } \\
\text { sectors of the economy, as well as the most } \\
\text { important groups of material and technical } \\
\text { resources and products }\end{array}$ \\
$\begin{array}{c}\text { The effectiveness and efficiency of methods } \\
\text { and methods for achieving goals with the least } \\
\text { cost of resources used }\end{array}$ & $\begin{array}{c}\text { Program-targeted management, the use of } \\
\text { progressive technical and economic norms and } \\
\text { standards for the consumption of material and } \\
\text { labor resources, as well as specific capital } \\
\text { investments }\end{array}$ \\
$\begin{array}{c}\text { Resource provision (within the established } \\
\text { limits) of strategic planning activities }\end{array}$ & $\begin{array}{c}\text { Balances for the main types of economic } \\
\text { activities and institutional sectors of economies } \\
\text { and the most important groups of material and } \\
\text { technical resources and products, determining } \\
\text { the need for material, labor resources and } \\
\text { capital investments on the basis of relevant } \\
\text { technical and economic norms and standards }\end{array}$ \\
\hline
\end{tabular}

In turn, the information base for strategic planning should comply with the following six methodological principles. The main one is the information security of calculations. As others, the following are used: methodological unity of the information base at various levels of management (the main link is enterprises and organizations, integrated corporate structures, industry and the national economy), the formation of norms and standards for the consumption of resources in natural and value terms, the ability to aggregate information by levels of management and progressiveness of the regulatory framework [14].

The mechanisms and procedures for fulfilling these requirements are shown in Table 3. 
Table 3. Mechanisms and procedures for ensuring the basic requirements for the regulatory framework of strategic planning

\begin{tabular}{|c|c|}
\hline Principle name & Implementation mechanisms and procedures - \\
\hline Information security & $\begin{array}{l}\text { Carrying out the necessary technical and economic calculations of } \\
\text { indicators of strategic planning documents on the basis of } \\
\text { progressive technical and economic norms and standards }\end{array}$ \\
\hline $\begin{array}{l}\text { Methodological unity } \\
\text { of indicators formed at } \\
\text { all levels of } \\
\text { management }\end{array}$ & $\begin{array}{c}\text { The procedure for determining and using material, labor and production } \\
\text { norms and standards in planned and forecast calculations, software for } \\
\text { calculating on a computer }\end{array}$ \\
\hline $\begin{array}{l}\text { Use of natural and } \\
\text { value meters of } \\
\text { norms and standards }\end{array}$ & $\begin{array}{l}\text { Determination of consolidated rates of resource consumption both in } \\
\text { kind (kilograms) per unit of technical parameter of } \\
\text { manufactured products (kWh, capacity, carrying capacity, etc.), and in } \\
\text { value terms. Linking the need for resources with the end results of } \\
\text { production activities - manufactured products. }\end{array}$ \\
\hline Aggregation & $\begin{array}{c}\text { Consolidation, consolidation of norms and standards by levels of } \\
\text { management by methods of grouping, summing (calculating average } \\
\text { and weighted average values), and other methods of converting } \\
\text { particular indicators into general - consolidated (weighting factors, } \\
\text { points, etc.). }\end{array}$ \\
\hline $\begin{array}{c}\text { Reasonableness and } \\
\text { progressiveness }\end{array}$ & $\begin{array}{l}\text { The assumption about the repeatability of production processes for } \\
\text { manufacturing products or performing work (rendering services) for } \\
\text { which planning standards are developed } \\
\text { Systematically carrying out the examination rules and regulations, the } \\
\text { development of organizational and - technical measures to reduce the } \\
\text { proportion of the cost of all kinds of resources per unit of production. }\end{array}$ \\
\hline Update & $\begin{array}{c}\text { Reflection of changes due to the influence of scientific and } \\
\text { technological progress in the regulatory framework of strategic planning } \\
\text { - a system of progressive norms and standards }\end{array}$ \\
\hline
\end{tabular}

The whole "piquancy" of the situation lies in the fact that at present practically no one is dealing with the issues of industrial development at the intersectoral level in the government on a systematic basis . The first sign in this direction can be considered the reestablishment of a commission on the development of the defense industry, chaired by Deputy Prime Minister Borisov O.G. In Soviet times, in addition to the consolidated and balance departments of the State Planning Committee of the USSR, special commissions created in the Council of Ministers of the USSR were also involved in solving cross-sectoral problems of industrial development: mechanical engineering, chemistry, emergency situations, the development of the agro-industrial complex and military -industrial issues. They were headed by leaders with at least the status of Deputy Chairman of the USSR Council of Ministers.

Special attention should be paid to the consideration of the issue of choosing a state executive body as a responsible executor of state programs for the development of the national economy of Russia. Potentially, the solution of such issues could be assigned for a number of reasons.

\section{Conclusion (recommendations)}

Currently, the methodology for the development of state programs suffers from a number of significant shortcomings, the main of which are the weak depth of their elaboration, on the one hand, and the ineffective use of program-targeted management, on the other hand. 
The proposals presented in the work will help to ensure an increase in the level of reliability and objectivity of government programs and priority financing of the most promising complex intersectoral and interregional problems.

\section{References}

1. N.D. Kondratyev, Selected Works (1993)

2. V.V. Leontiev, Economic essays, Research theory, facts and politics (2003)

3. L.V. Kantorovich, Mathematical methods of organizing production planning (1939)

4. I.A. Afonina, O.D. Ivanova, O.E. Panasevich, Strategic planning in the face of growing external threats: the need to mobilize internal resources for the development of Russia, 6 (2014)

5. A.V. Buzgalin, A.I. Kolganov, The revival of planning, lessons (political and economic discourse, Problems of the theory of management practice, 1 (2016)

6. R.S. Greenberg, Formation of the domestic market economy, 11 (2007)

7. E.M. Bukhvald, Strategic long-term construction; is the result visible?, STAGE. Economic theory, analysis, practice, 6 (2017)

8. A.A. Gaganov Does Russia have strategic planning?, Scientific Political Thought and Ideology Center. 2018. Available from https://rusrand.ru/analytics/est-li-v-rossiistrategicheskoe-planirovanie (accessed 01.11.2020).(In Russ.).

9. V.V. Klimanov, K.V. Budaeva, N.A. Chernyshova, Interim results of strategic planning in the regions of Russia, Economic Policy, 5 (2017)

10. V.E. Seliverstov, Strategic planning and strategic miscalculations; Russian realities and trends, Region, Economics and Sociology, 4 (2016)

11. G.B. Kleiner, Development of the theory of economic systems and its application in corporate and strategic management: preprint (2010)

12. G.B. Kleiner, Systemic bases of digital economy, Philosophy of economy, 1 (2018)

13. Yu.V. Mishin, A.Yu. Mishin, Organizational and methodological problems of creating a regulatory framework for strategic planning in Russia (2016)

14. Yu.V. Mishin, O.M. Pisareva, A.Yu. Mishin, V.A. Alekseev, Regulatory framework for strategic planning: foundations, unsolved problems and directions of development (2019)

15. O.O. Smirnova, Paradigms and parallels. On the change of the paradigm of the unipolar world in strategic planning, MIR (Modernizaciâ. Innovacii. Razvitie), 19 (2014)

16. O.O. Smirnova, Normative, legal and methodological aspects of the formation of balances of labor resources in the strategic planning system of the Russian Federation Economics, politics, law (2019)

17. D.V. Thanh, Macro-econometric model for medium-term socio-economic development planning in Vietnam. Part 2: Application of the model, Economy of Region, 15 (2019)

18. Guidelines for the development of state plans for the economic and social development of the USSR (1980)

19. A.B. Zolotareva, I.A. Sokolov, Problems and ways of improving the system of strategic planning in Russia. Ekonomicheskaya Politika, 13 (2018)

20. Methods for the development of natural - value models of the economy. Scientific works (1973) 
21. Order of the Ministry of Economic Development of Russia dated September 16, 2016 No. 582, as amended on March 5, 2017, http://www.consultant.ru/

22. The decree of the State Planning Committee of the USSR dated July 3, 1980, No. 117, http://www.consultant.ru/ 